\title{
NEW ETHIOPIAN FRUIT-FLIES OF THE GENUS DACUS.
}

\author{
By Prof. M. Bezzi.
}

Since the publication of my previous paper on the Ethiopian fruit-flies of the genus Dacus, ${ }^{*}$ I have received some additional species, the descriptions of which are given in the following pages, with the purpose of completing our knowledge of this very important genus of Diptera. For the material here illustrated I am indebted to Dr. Guy A. K. Marshall, Director of the Imperial Bureau of Entomology, and to Dr. Alberto Mochi, of Ghinda, Erythraea: to whom I have to offer my best thanks.

\section{Subgenus Tridacus, Bezzi, 1915.}

\section{Tridacus d'emmerezi, sp. nov. (fig. 1).}

Very distinct from any other known species of the present group, on account of the broad fuscous patch on the middle of wings, around the small cross-vein.

oㅇ․ Length of body, 7-9 $\mathrm{mm}$. ; length of wing, 6-7 $\mathrm{mm}$.

Body of a uniform reddish colour, with less striking yellow and brown markings; thorax and abdomen with short yellowish pubescence on the disk; all the bristles of head and thorax black. Head of a more yellowish colour, opaque, but shining on the occiput, which has a paler border near the eyes; ocellar dot dark brown, on a brown transverse band; frons with a less developed fuscous middle spot, with almost indistinct dark dots on the sides and with two pairs of lower frontoorbital bristles, which are not approximated; lunula reddish brown, shining; face with shining antennal grooves, in the middle of which are placed the very small and rounded black spots; peristomial spot dark brown. Antennae much elongated, with the first joint about as long as the second; they are entirely reddish, the third joint being sometimes a little infuscated at the distal end; palpi very broad, pale yellowish, almost bare. Thorax with some irregular, blackish markings on the disk, forming two more or less distinct longitudinal stripes, which do not reach the scutellum, or two less distinct broader interrupted stripes along the dorsocentral lines. Yellow markings as follows: humeral calli entirely; a narrow stripe along the transverse suture, broadly interrupted in the middle, and continued on the pleurae with the broader mesopleural band, which ends with a small spot on the upper border of the sternopleura; two broad contiguous hypopleural spots, which are margined inwardly, in front of the insertion of the halteres, with a conspicuous blackish patch. The anterior supraalar bristle is well developed, like the two posterior ones; the four scapular ones are long and strong; the pteropleural is well developed. Scutellum yellow, with the base narrowly reddish brown, and with a pair of long apical bristles. Mesophragma reddish, with the above-mentioned dark spot on the sides. Halteres whitish yellow. Abdomen elongate, rather constricted near the base; hind border of the second segment with a broad yellowish band, which is more or less interrupted in the middle; sides of the first. sometimes of the second and middle of the third segments provided with more or less distinct, but not sharply defined, dark brown

*Bull. Ent. Research, vi., Sept. 1915, pp. 85-101, 14 figs. 
or blackish markings; venter reddish, the second segment with a yellow band. Third segment of the male with 8-10 long, black cilia at the sides of the hind border; ovipositor not longer than the last abdominal segment, reddish yellow, with the basal segment depressed. Legs of a prevalent pale reddish colour, but the coxae and the trochanters dark reddish-brown or blackish; the basal half of the femora and all the praetarsi pale yellowish. Wings (fig. 1) of rather large size, with the veins reddish yellow; last portion of fourth vein gently bisinuous; second longitudinal vein long, the distance of its end from that of the first being not much shorter than the distance from that of the third; small cross-vein long, its lower end placed much after the middle of the discal cell; lower prolongation of the anal cell longer than the distance of its end from the hind border of the wing. They are hyaline, with a broad, pale yellowish fore border; which includes the stigma, but excludes the costal cells, and is not extended over the third vein, or only a little; in contact with this border is a broad and more infuscated patch, surrounding the small cross-vein and encroaching more or less on the upper end of the discal cell. Anal stripe very broad and more infuscated than the marginal one.

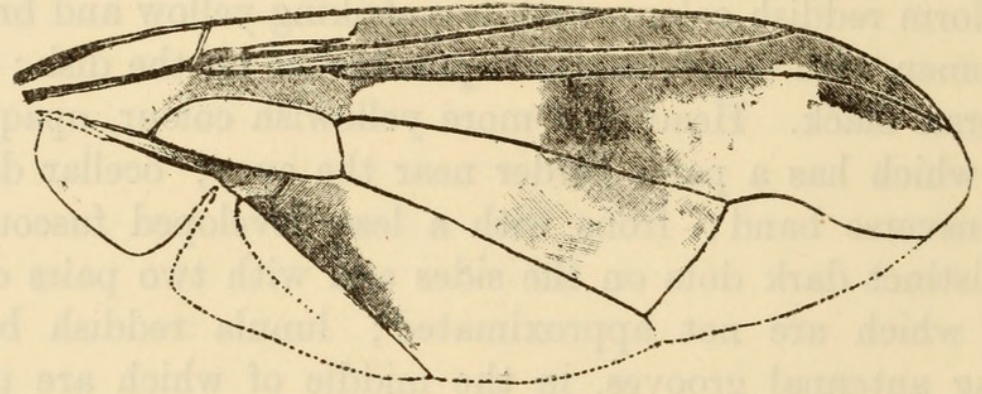

Fig. 1. Tridacus d'emmerezi, Bezzi, sp. n.

Type $\sigma^{t}$ and type , and some additional specimens, in the collection of the Imperial Bureau, from Mauritius, Reduit, 1916, collected by Mr. D'Emmerez de Charmoy, in whose honour this interesting species is named.

II. Subgenus Dacus, Bezzi, 1915.

In my Key to the species (l.c., p. 89) the section 21 (22) must be amplified as follows:-

21 (22). Face without black spots.

$a(b)$. Two contiguous hypopleural spots; third abdominal segment of male ciliated; wings with a brown anal stripe .. .. immaculatus, Coq.

$b(a)$. A single hypopleural spot; male with the third abdominal segment not ciliated; wings without an anal stripe.

$c(d)$. Frons with three pairs of blackish dots near the eyes; abdomen entirely black along the middle line; wings with the submarginal cell hyaline at base over the small cross-vein. . . . . . annulatus, Becker.

$d(c)$. Frons with the basal half brown, the apical half yellowish, and without black dots; abdomen with a broad, reddish yellow, longitudinal middle band, which is divided by a black line; wings with the submarginal cell broadly infuscated at base and with the upper end of the small cross-vein margined with fuscous .. $\quad . . \quad$.. moch $i$, sp. n. 
2. Dacus annulatus, Becker, 1903 (fig. 2).

An elegant species, well distinguished by the entirely black yellow-marked body, by the unspotted face, by the single hypopleural spot, by the unciliated third abdominal segment of the male, and by the lack of the anal stripe on the wings.

The face is unspotted, but usually there is a more or less developed black or blackish spot on the upper edge of the clypeus, just below the base of antennae. All the bristles are black; two pairs of distant lower fronto-orbital bristles; only the external scapular bristles are well developed, the middle ones being rudimentary; no anterior supra-alar; pteropleural well developed. The sutures of the abdominal segments are partly fused in the middle. The legs are pale yellowish, as described by the author; but in some $\hat{\sigma}$ specimens the apical third of the hind femora, and sometimes the whole of the hind tibiae, are black. Wings (fig. 2) with the second longitudinal vein short, the fourth segment of the costa being about one-third the length of the fifth; prolongation of the anal cell not longer than its distance from the hind border.

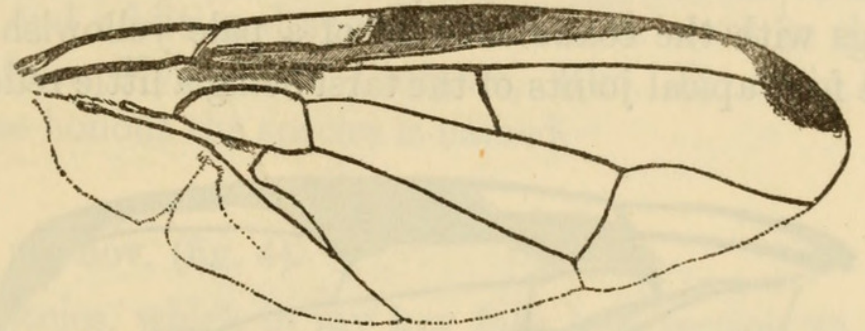

Fig. 2. Dacus annulatus, Becker.

The present species was collected by Ehrenberg in Egypt about a century ago and described rather recently by Becker from the original specimens; I have before me numerous examples from Ghinda, Erythraea, December 1916, collected by $\operatorname{Dr}$. A. Mochi, who has found the species very common there. This species has already been recorded from Erythraea (Asmara, leg. Kristensen) by Dr. Enderlein and by Dr. Speiser, both in 1911.

3. Dacus mochii, sp. nov. (fig. 3).

Nearly allied to the preceding species, but at once distinguished by the very differently coloured frons and abdomen, and by the peculiar wing-pattern.

ऽ. Length of body, 5.5-6 mm. ; length of wing, $4 \cdot 5-5 \mathrm{~mm}$.

Occiput shining black above, with a narrow yellowish border, and pale yellowish below; ocellar dot black; frons with the basal half infuscated, the apical half pale yellowish, destitute of blackish lateral dots; lunula shining brown; face pale yellowish, immaculate, shining only along the antennal grooves; peristomial spot wanting. Antennae of moderate length, the first joint not elongated; they are dark yellowish, with the third joint infuscated at the distal end; palpi and proboscis pale yellowish. The bristles of the head are black; there are two pairs of lower fronto-orbitals, one very near the dividing line between the face and frons, the other at the level of the dividing line between the dark and the clear portions of the frons. Thorax entirely black, even on the pleurae, with short whitish 
pubescence on the back. The wax-coloured markings are as follows : humeral calli entirely; a short and narrow stripe on each side of the transverse suture; a very broad, spot-like patch (about double as broad as the corresponding band of annulatus) occupying almost the whole of the mesopleura and the adjoining part of the pteropleura, ending with a small spot on the upper border of the sternopleura; a single rounded hypopleural spot. Mesophragma entirely black. Scutellum wax-coloured, with a very narrow, black, basal stripe. Halteres whitish. All the bristles are black; no trace of anterior supra-alars ; pteropleurals weak ; scapulars not distinguishable in the type; two scutellars. Abdomen ovate, punctate and pubescent like the pronotum, a little constricted near the base ; it is black, but has a broad yellowish band at hind border of second segment, like annulatus, and besides a broad yellow middle band extending from hind border of second segment to the end, where it is dilated and occupies almost the whole hind half of the last segment; along the middle of this yellow band there is a narrow black stripe, dilated at base and attenuated before reaching the tip; the sutures of the segments are partly fused and the third is not ciliated at the sides. Venter yellow, with dark or blackish sides; genitalia reddish. Legs with the coxae entirely of a pale yellowish colour, the ends of the femora and the four apical joints of the tarsi being a little reddish. Wings (fig. 3)

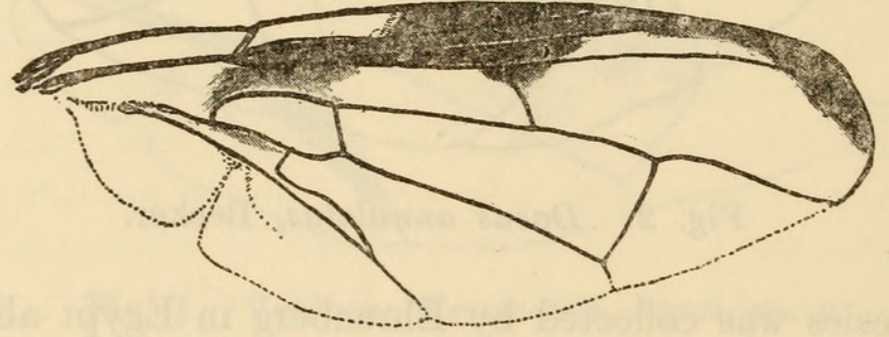

Fig. 3. Dacus mochii, Bezzi, sp. n.

hyaline, with brownish veins; second vein short; small cross-vein a little beyond the middle of the discoidal cell ; last portion of fourth vein gently curved at base ; prolongation of the anal cell proportionally short. There is a narrow blackish fore border, which leaves the costal cells hyaline, but is more intensively coloured on the stigma; below this, the fore border is dilated, filling broadly the base of the submarginal cell and surrounding the upper end of the small cross-vein; at its end the marginal band is a little dilated, but without forming a distinct spot at the end of third vein. There is no trace of an anal stripe, the anal cell being only a little yellowish on its upper half.

Type $\hat{\sigma}$, and an additional specimen of same sex, in the writer's collection, taken near Ghinda, Erythraea, December 1916, by Dr. Alberto Mochi, in whose honour the species is named.

\section{Dacus woodi, sp. nov.}

Exceedingly close to the preceding species (D. mochii), and resembling it in its unspotted face and unciliated third abdominal segment of the male, but differing in the colour of hody and in the not infuscated upper end of the small cross-vein. 
๙우. Length of body, $5.5-6 \mathrm{~mm}$. ; length of wing, $4.5-5 \mathrm{~mm}$. The species differs from $M$. mochii in the following points :-

(1). The basal half of frons is yellowish, and therefore there is a very distinct dark transverse band on the middle; the lunula is pale yellowish, not brown. (2). The thorax is prevalently of a reddish, not black, colour, chiefly in front and on the pleurae; all the markings and the scutellum are of a bright yellow colour; the mesophragma is distinctly reddish on the sides, not entirely black. (3). The abdomen has the second segment more broadly yellow; the longitudinal yellow band is broader and has no middle black line in the male. (4). The wings have the base of the submarginal cell broadly infuscated, but this infuscation is not continued over the upper end of the small cross-vein.

The female is very like the male, but the abdomen has the second segment more broadly black, and there is a middle black line in the longitudiual yellow stripes. Ovipositor entirely reddish-yellow, shining, with the basal segment swollen, about as long as the last abdominal segment, but not much prominent.

Type $\hat{\sigma}$, type $ᄋ$ and additional specimens of both sexes in the collection of the Imperial Bureau, from Nyasaland, Chiromo, Ruo. R., 22.ix.1916, collected by $R$. C. Wood, in whose honour the species is named.

\section{Dacus hamatus, sp. nov. (fig. 4).}

A very distinct species, which in my key falls into section 25 (p. 90), but is distinguished from inornatus and from any other known species by the exceedingly peculiar wing pattern, and by the longitudinal keel of the abdomen.

1우. Length of body, 6-6.5 mm. ; length of wing, $5-5.5 \mathrm{~mm}$.

Head entirely of a shining black colour, even on frons and face; occiput with a narrow and short, spot-like stripe on each side on the orbits; frons with a pair of yellow dots on the basal half; lunula yellowish brown; the frons shows anteriorly a rounded prominence, which is peculiar to this species. Antennae dark yellowish, with the two basal joints very short, the second with some black bristles above, the third very elongate, blackish on the apical half ; palpi broad, of a reddish colour; proboscis black. Cephalic bristles black; two pairs of distant lower fronto-orbitals. Thorax entirely black, punctate, with a short dark pubescence on the back, which is paler at the sides. The very striking yellow markings are as follows : a rounded humeral spot, which covers only the hind half of the humeral calli; the fore half being black; there is no sutural stripe, only the notopleural calli at the beginning of the suture being yellow; an oval spot in the middle line of the back, behind the suture; a broad mesopleural patch, extended on to the pteropleura and ending with a small spot on upper border of sternopleura; a single hypopleural spot Mesophragma entirely black, punctate, a little shining. Halteres pale yellowish. Scutellum yellow, with a narrow black base and with a pair of bristles. All the bristles are black; there is no trace of anterior supra-alars; pteropleurals well developed; only the external scapulars are strong. Abdomen rounded, convex, constricted at base ; along the middle line there is a very peculiar obtuse keel, which on the middle segments is rather prominent; it is clothed with dark pubescence, which at the sides of the base is greyish, erect and rather long. The abdomen is. 
entirely black, opaque, punctate; only the last segment is more or less reddish in the middle of the hind border; the segments are fused together in the middle, and the third of the male is not ciliated; ovipositor shining black, smooth, with the basal segment swollen and of conical shape, not longer than the last abdominal segment; apical segment short, reddish yellow. Venter entirely black; male genitalia dark brown, surrounded with yellowish. Legs with coxae, trochanters and femora shining black, but the middle pair with a narrow base, and the hind pair with more than the basal half, yellowish; tibiae yellowish, with blackish or darkened basal half ; tarsi pale yellowish, with whitish basal joints. Wings (fig. 4) hyaline, with yellowish veins, which are darkened on the dark markings; second vein long, its distance from the end of the third being only $1 \frac{1}{2}$ times longer than that from end of the first; third vein straight at the end and parallel with the last portion of the fourth, which is only a little curved near the base ; the lower end of the small cross-vein is placed at the middle of the discal cell ; the prolongation of the anal cell is shorter than the remainder of the anal vein.* The dark pattern consists of the black stigma, the infuscated bases of the marginal and submarginal

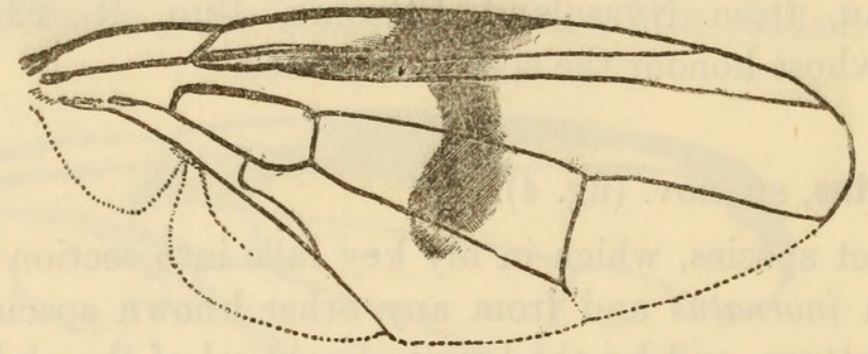

Fig. 4. Dacus hamätus, Bezzi, sp. n.

cells, and a very peculiar, hook-shaped band, which passes over the small cross-vein, crosses the middle of the discal cell and ends sometimes with a short prolongation in the third posterior cell. There is no trace of an apical spot or anal stripe.

Type $\hat{\sigma}$ and type $q$, and some additional specimens of both sexes, in the collection of the Imperial Bureau, from Nyasaland, Chiromo, Ruo. R., 11.v.1916 (R. C. Wood).

The present species, with its characteristic wing pattern, seems to approach to the Oriental species with banded wings, for which I have preserved the genus Bactrocera in a restricted sense; these last species however are always provided with a pair of praescutellar bristles.

\section{Dacus blepharogaster, sp. nov. (fig. 5).}

Falling into section 28 of my Key (p. 90), but very different from rufus on account of its prevalently black colour; it is besides distinguished from annulatus and mochii, to which it is allied in general appearance, by the black-spotted face and by the ciliation of the third abdominal segment in the male.

o. Length of body, $7 \mathrm{~mm}$; length of wing, $6 \mathrm{~mm}$.

* All these peculiarities of the venation are to be found also in the nearly allied inornatus, Bezzi, which however has no trace of the longitudinal keel on the abdomen. 
Head yellowish; occiput shining, with the vertex reddish with two black spots and with a broad blackish patch on each side; orbits yellow, broadened below; ocellar dot black; frons opaque, with three pairs of blackish dots on the sides and an undetermined fuscous patch in the middle; lunula shining black; face entirely shining, with a broad rounded black spot on lower half of each antennal groove; peristomial spot broad and black. Antennae entirely reddish yellow, the third joint a little infuscated at the end, the first joint much shorter than the second; palpi and proboscis reddish yellow. Cephalic bristles black; two pairs of distant lower fronto-orbitals. Thorax entirely black, slightly reddish on the sides in the hind half and along the pleural sutures, chiefly on the front half. The bright yellow markings are as follows: humeral calli entirely; a short triangular stripe along the sides of the transverse suture; a rather broad mesopleural stripe, ending with a spot on upper border of sternopleura; a single hypopleural spot. The back is punctate and clothed with short greyish pubescence; mesophragma entirely black. Scutellum bright yellow, with a narrow black basal line. Halteres whitish. All the bristles are black; no trace of anterior supra-alars; the middle scapulars are well developed, like the external ones; pteropleurals rather weak; a single pair of scutellar bristles. Abdomen in shape, colouring, punctuation and pubescence like that of annulatus; but it is less elongate, more oval; the hind

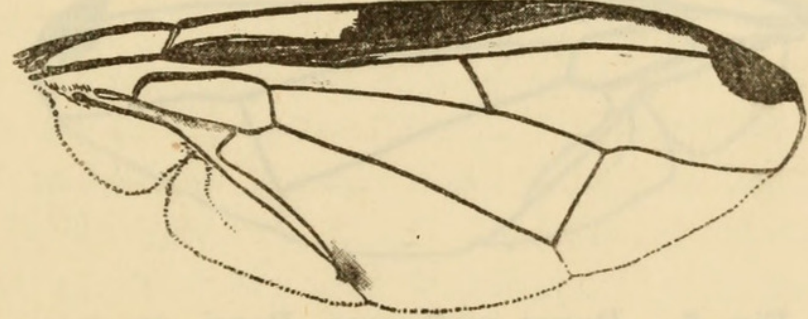

Fig. 5 Dacus blepharogaster, Bezzi, sp. n.

border of the third segment has also a narrow yellowish band; third segment with 6-7 black cilia at the sides of the hind border. Legs with the coxae pale yellowish, the middle and hind femora being dark reddish at the end; all the tibiae are broadly darkened, the posterior ones being entirely black; tarsi reddish brown, with all the praetarsi whitish. Wings (fig. 5) hyaline, with the fore border and the apical spot as in annulatus, but there is a distinct greyish spot before the end of the anal vein, which is entirely wanting in that species. The veins are yellowish and their disposition is like that of annulatus, but the prolongation of the anal cell is much more developed, being longer than the rest of the anal vein.

Type $\hat{\sigma}$, a single specimen in the writer's collection, taken near Ghinda, Erythraea, 7.xi.1916, by Dr. Alberto Mochi.

\section{Dacus erythraeus, sp. nov. (fig. 6).}

Allied to the preceding species, but distinguished by the smaller facial black spots and by the non-ciliated third abdominal segment of the male; and also differing from it and from annulatus and mochii by the broader black base of the scutellum and by the isolated blackish apical spot of the wings. 
In my Key the present species falls into section 27 (p. 90) together with oleae, which also occurs in Erythraea,* but has no real affinity with it.

cㅇ․ Length of body, $5 \cdot 5-6.5 \mathrm{~mm}$. ; length of wing, $5-6 \mathrm{~mm}$.

Occiput black, rather shining, with narrow yellowish orbits, which are broadened below; ocellar spot shining black; frons opaque, with the basal half reddish brown and the apical half pale yellowish, but with three distinct pairs of broad blackish dots on the sides; lunula shining red or brownish; face pale yellowish, shining, the black spots being more stripe-like and placed on the inner border of the antennal grooves near the mouth-border; peristomial spot less darkened, but distinct. Antennae reddish, with the first joint short and the third infuscated at the end; palpi pale yellowish; proboscis reddish. Cephalic bristles black; two pairs of strong and distant lower fronto-orbitals. Thorax entirely black, even on the pleurae, or only with a reddish stripe near the prothoracic stigma. Yellow markings as follows: humeral calli entirely, but with a black border above and in front; a narrow, triangular and short sutural stripe on each side; a rather narrow mesopleural stripe, ending with a very small and less distinct sternopleural spot; a single hypopleural spot, which is broadly margined with black below. Scutellum bright yellow, with a basal black band, which is much broader than

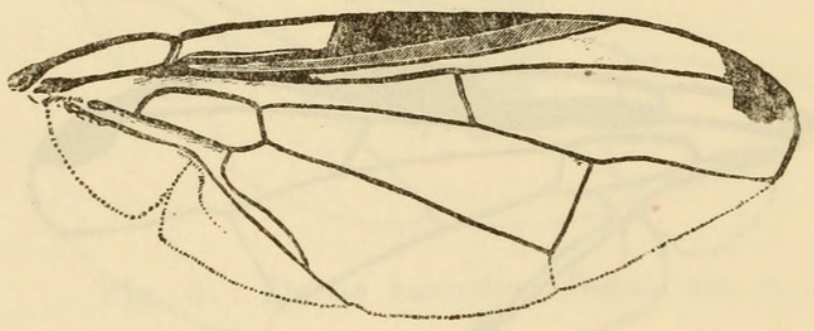

Fig. 6. Dacus erythraeus, Bezzi, sp. n.

in all the preceding species. Mesophragma entirely black. The back of the thorax is punctate and clothed with short whitish pubescence. The bristles are black; no anterior supra-alars; scapulars short, the middle ones not distinct; pteropleurals well developed; two scutellar bristles. Halteres whitish. Abdomen elongate in the male, more rounded in the female, convex, punctate, with whitish pubescence, which on the sides is rather long. It is black; the second segment has a rather broad, pale yellowish, transverse band at the hind border, which is broadly interrupted in the middle; fourth and fifth broadly reddish in the middle, forming a triangular patch with the base behind and provided with a middle longitudinal black line, which does not reach the hind border of the last segment. Venter yellowish, irregularly blackened towards the middle. Male with non-ciliated third abdominal segment and with shining red genitalia. Ovipositor short, as long as the last abdominal segment, but not prominent, reddish, with the basal segment rather inflated but not conical. Middle segments of the abdomen in both

* F. Silvestri. Viaggio in Eritrea per cercare parassiti della mosca delle olive (Boll. del Labor. di Zool. gen. e agr., Portici, 1914, ix, pp. 186-226, 24 figs.).

F. Silvestri. Contributo alla conoscenza degli insetti dell' olivo dell' Eritrea e dell' Africa meridionale (l.e., 1915, ix, pp. 240-334, 78 figs.). 
sexes with the sutures partly obliterated. Legs pale yellowish; front femora brownish at the end; four posterior femora broadly black at the end; middle tibiae black at the base exteriorly, hind tibiae entirely black; praetarsi paler than the other joints. Wings (fig. 6) hyaline, with blackish veins; second vein short, the fourth segment of the costa being about one-third the length of the fifth; third vein rather straight and parallel with the last portion of the fourth, which is less curved near the base ; lower end of the small cross-vein placed after the middle of the discal cell; prolongation of the anal cell longer than the remainder of the anal vein. The very reduced pattern consists only of the black stigma, the infuscated marginal cell and an isolated blackish spot at the end of the third vein; there is no distinct grey spot at the end of the anal cell.

Type $\hat{\sigma}$ and type , a single pair of specimens in the author's collection, from Ghinda, Erythraea, 3.xii.1916, collected by Dr. Alberto Mochi. 


\section{$2 \mathrm{BHL}$ Biodiversity Heritage Library}

1917. "New ethiopian fruit-flies of the genus Dacus." Bulletin of entomological research 8, 63-71. https://doi.org/10.1017/S0007485300036518.

View This Item Online: https://www.biodiversitylibrary.org/item/109952

DOI: https://doi.org/10.1017/\$0007485300036518

Permalink: https://www.biodiversitylibrary.org/partpdf/48921

\section{Holding Institution}

Smithsonian Libraries

\section{Sponsored by}

Biodiversity Heritage Library

\section{Copyright \& Reuse}

Copyright Status: Public domain. The BHL considers that this work is no longer under copyright protection.

This document was created from content at the Biodiversity Heritage Library, the world's largest open access digital library for biodiversity literature and archives. Visit BHL at https://www.biodiversitylibrary.org. 